\title{
KOMPARASI INFORMATION TECHNOLOGY PROCUREMENT POLICY DI PEMERINTAHAN
}

\author{
Fahmy Asa \\ Departemen Teknik Elektro dan Teknologi Informasi, Program Studi S2 Teknik Elektro, Konsentrasi Teknologi \\ Informasi, Fakultas Teknik, Universitas Gadjah Mada \\ Jalan Grafika Nomor 2 Kampus UGM, Sleman 55281 \\ E-Mail : fahmy.cio.7a@mail.ugm.ac.id
}

\begin{abstract}
ABSTRAK
Pemerintah melakukan Pengadaan Teknologi Informasi untuk mengakuisisi produk dan layanan Teknologi Informasi. Belanja TI pemerintah mengambil porsi signifikan dari anggaran pemerintah keseluruhan. Penerapan kebijakan Pengadaan Teknologi Informasi (IT Procurement Policy) yang baik perlu dilakukan untuk efisiensi anggaran dan efektivitas kegiatan pemerintah. Penelitian ini membandingkan kebijakan Pengadaan Teknologi Informasi di 3 (tiga) negara, yakni Indonesia, Australia, dan Singapura dengan mendasarkan pada prinsip kebijakan Pengadaan Berkelanjutan (Sustainable Procurement) yang termuat dalam standar internasional ISO 20400. Prinsip yang termuat dalam ISO 20400 sustainable procurement antara lain adalah Akuntabilitas, Transparansi, Etika, Kepentingan Stakeholders (stakeholders interests), Respek terhadap Aturan Hukum dan Norma Internasional, Solusi Inovatif dan Transformatif, Fokus pada Kebutuhan, Integrasi, dan Global Cost. Hasil komparasi menunjukkan kesamaan dan perbedaan prinsip kebijakan Pengadaan Teknologi Informasi (IT Procurement Policy) di masing-masing negara. Prinsip-prinsip yang telah digunakan oleh negara Australia dan Singapura diadopsi untuk dapat diterapkan di level kebijakan di Indonesia. Kata Kunci : IT Procurement Policy, TIK, Kebijakan Pengadaan Teknologi Informasi Pemerintah.
\end{abstract}

\section{PENDAHULUAN}

Dari tahun ke tahun, anggaran belanja teknologi informasi pemerintah mengalami kenaikan. Seperti halnya anggaran belanja pemerintah lainnya, untuk merealisasikan anggaran belanja teknologi informasi, pemerintah harus melalui rangkaian proses pengadaan atau lelang barang dan jasa.

Meski demikian, kegiatan pengadaan di pemerintah Indonesia masih memiliki berbagai permasalahan. Pengadaan pemerintah, khususnya di bidang Pengadaan Teknologi Informasi, menghadapi beberapa kendala seperti: permasalahan penyusunan anggaran untuk Pengadaan Teknologi Informasi, penyusunan kebutuhan untuk pengadaan (requirements), pembahasan kontrak, dan lain lain.[1] Selain itu, pengadaan Teknologi Informasi kerap menjadi sumber inefisiensi anggaran. Belanja TI yang besar memunculkan risiko penyelewengan yang besar pula. Oleh karenanya, perlu pengawasan pengadaan Teknologi Informasi pemerintah dengan mengedepankan aspek transparansi dan kualitas.

Keberhasilan implementasi Teknologi Informasi di Pemerintah harus didasari oleh landasan kebijakan yang baik. Saat ini belum ada kebijakan khusus Pengadaan Teknologi Informasi (IT Procurement Policy) di Pemerintah Indonesia. Berdasarkan hal tersebut, studi komparasi diperlukan guna mengetahui bagaimana upaya negara lain yang sudah berhasil melakukan implementasi kebijakan Pengadaan Teknologi Informasi di negaranya. Komparasi tersebut nantinya dapat dijadikan sebagai salah satu bahan acuan bagi pengembangan kebijakan Pengadaan yang sudah ada. Penelitian ini bertujuan mengumpulkan dan menganalisis dokumen kebijakan Pengadaan Teknologi Informasi di Indonesia, Australia dan Singapura, untuk mengidentifikasi penerapan kebijakan tersebut. Untuk mengidentifikasi dasar kebijakan sekaligus persamaan dan perbedaannya, beberapa pertanyaan perlu dicari jawabannya, yaitu: apa prinsip-prinsip dasar yang membentuk kebijakan Pengadaan Teknologi Informasi? Unsur-unsur apa yang memiliki kesamaan dalam kebijakan masingmasing negara? Apakah ada perbedaan dalam kebijakan masing-masing negara? Apakah ada elemen perbedaan dari negara yang lain yang dapat diimplementasikan di Indonesia.

Sistematika dalam penulisan penelitian ini adalah sebagai berikut: setelah bagian Pendahuluan, selanjutnya dibahas mengenai kerangka teori yang melandasi kebijakan pengadaan TI di pemerintahan. Di bagian 3 akan dibahas mengenai metodologi yang digunakan dalam assessment terhadap kebijakan pengadaan teknologi informasi di tiga negara, dan bagian 4 akan menguraikan tentang hasil dan pembahasan dari perbandingan kebijakan 3 negara. Dan di bagian 5 memuat kesimpulan serta saran dan rekomendasi.

\section{TINJAUAN PUSTAKA}

Beberapa peneliti telah melakukan studi tentang pengadaan atau akuisisi sistem informasi di pemerintah. Harahap [1] mengidentifikasi 
permasalahan-permasalahan

pengadaan infrastruktur TI di pemerintah Indonesia. Beberapa permasalahan tersebut antara lain adalah penyusunan anggaran, pembentukan tim pengorganisasian pengguna (user), pembuatan kebutuhan (requirements), perencanaan pengadaan, penerbitan RFI (request for information) dan RFQ (request for qualification), penentuan lingkup pengadaan, penulisan RFP (request for proposal), penerbitan RFP dan pengendalian pengadaan, pengajuan dan persetujuan pemenang, pembahasan kontrak, penyerahan barang/jasa, uji-terima, dan operasi serta dukungan teknis.

Penelitian lain tentang pengadaan sistem informasi (SI) di pemerintah dilakukan oleh Moe, Risvand, dan Sein [2]. Analisis kasus akuisisi dua sistem informasi di pemerintah lokal di Norwegia menunjukkan bahwa penyusunan spesifikasi sistem merupakan salah satu faktor terpenting dalam akuisisi Sistem Informasi pemerintah. Spesifikasi sistem/kebutuhan yang jelas, lengkap, dan layak, menjadi penting, mengingat regulasi dalam pengadaan barang/jasa pemerintah mensyaratkan hal tersebut. Meski demikian, kondisi tersebut menjadi dilematis mengingat kebutuhan/spesifikasi SI cenderung mengalami perubahan pada saat masuk ke tahap pengembangan sistem (development). Selain itu, spesifikasi sistem yang terlalu detail juga dapat mengurangi minat vendor untuk mengikuti proses pengadaan. Vendor-vendor lebih memilih persyaratan teknis yang tidak spesifik agar mereka bisa menunjukkan kemampuan dan kualitas yang mereka miliki. Penelitian ini berhasil mengidentifikasi kondisi dilematis dalam Pengadaan/akuisisi Sistem Informasi.

Moe dan Newman [3] melakukan studi kasus terhadap pengadaan sistem informasi di 3 (tiga) pemerintah lokal di Norwegia. Penelitian ini menggarisbawahi pentingnya aspek penentuan requirements secara lengkap. Penelitian ini menyatakan perlunya dilakukan studi interpretasi dan studi kasus yang lebih mendalam untuk mengurai proses procurement khususnya berkenaan dengan penentuan spesifikasi kebutuhan dan manajemen stakeholders pengadaan.

Walker [4] meneliti perbandingan kebijakan sustainable procurement di beberapa negara yang tergabung dalam organisasi OECD (Organisation for Economic Co-Operation and Development). Analisis dokumen kebijakan sustainable procurement di 30 negara dilakukan untuk mengidentifikasi elemen apa saja yang melatari konten kebijakan, serta untuk mengetahui penekanan aspek sustainable procurement di tiap negara. Penelitian dilakukan dengan metode analisis isi/content analysis. Penelitian ini menemukan bahwa kebijakan sustainable procurement bervariasi di banyak negara. Hasil temuan lain adalah bahwa negara Inggris, Australia dan Selandia Baru memiliki panduan kebijakan sustainable procurement yang paling komprehensif.
Sustainable Procurement atau Pengadaan Berkelanjutan dalam terminologi umum berarti upaya untuk memastikan bahwa barang/produk dan jasa/layanan yang diadakan oleh organisasi memiliki dampak ekonomi, sosial, dan lingkungan yang positif. Sustainable Procurement hendaknya tidak dipandang sebagai sebuah tujuan idealistik atau abstrak, akan tetapi sebagai sebuah sasaran realistis, praktis, dan reasonable, untuk semua organisasi baik publik maupun privat, seberapapun besarnya aktivitas atau ukuran organisasi tersebut.

Prinsip Sustainable Procurement seperti yang tercantum dalam ISO 20400 adalah sebagai berikut :akuntabilitas: transparansi, perilaku yang beretika: respek pada aturan hukum dan norma internasional: solusi inovatif dan transformatif: fokus pada kebutuhan, integrasi, global cost.

Prinsip Sustainable Procurement dari ISO 20400 merupakan prinsip Pengadaan yang menjadi acuan bagi organisasi-organisasi yang ada di dunia, salah satunya adalah negara/organisasi pemerintahan. Pada bagian selanjutnya, akan dibahas mengenai sistem pengadaan negara-negara yang menjadi objek dalam penelitian ini.

\subsection{Kebijakan Pengadaan Teknologi Informasi Pemerintah Indonesia}

Pengadaan barang dan jasa merupakan salah satu bidang di pemerintahan yang diatur dalam serangkaian peraturan dan perubahannya. Pengadaan teknologi informasi di pemerintah Indonesia berpedoman pada Peraturan Umum Pengadaan Barang dan Jasa Pemerintah. Pedoman Peraturan ini adalah Perpres 54 tahun 2010, yang berisikan prinsip-prinsip pengadaan secara umum, yaitu : Efisien, Efektif, Transparan, Terbuka, Bersaing, adil/tidak diskriminatif, dan Akuntabel.

Pada Bagian Kedua Perpres No. 54 Tahun 2010, terdapat pula prinsip Etika Pengadaan yang harus dipatuhi oleh para pihak yang terkait dalam pelaksanaan Pengadaan Barang/Jasa.[5]

\subsection{Kebijakan Pengadaan Teknologi Informasi Pemerintah Singapura}

Fokus pengadaan TIK pemerintah Singapura adalah memanfaatkan layanan dan produk teknologi informasi seperti big data dan cloud menuju digital government. Pemerintah Singapura mengembangkan kebijakan progresif untuk mewujudkan transformasi digital dalam tata pemerintahannya. Pemerintah Singapura mengembangkan sistem pengadaan produk/barang dan layanan/jasa TI untuk mempermudah proses pengadaan melalui bulk tenders dan melalui penyedia layanan/produk yang sudah terpercaya. Dengan cara demikian, instansi pemerintah dapat melakukan efisiensi dan mendapatkan nilai tambah yang lebih baik.

Kementrian Keuangan Singapura memiliki tanggung jawab dalam penyusunan framework kebijakan Pengadaan Pemerintah. Sebagai negara 
yang terlibat dalam kesepakatan WTO (World Trade Organisation) tentang Pengadaan Pemerintah, framework Pengadaan Pemerintah Singapura harus terselaraskan dengan prinsip standar internasional untuk Pengadaan, yaitu prinsip keadilan (fairness), transparansi, dan valuefor-money (VfM).

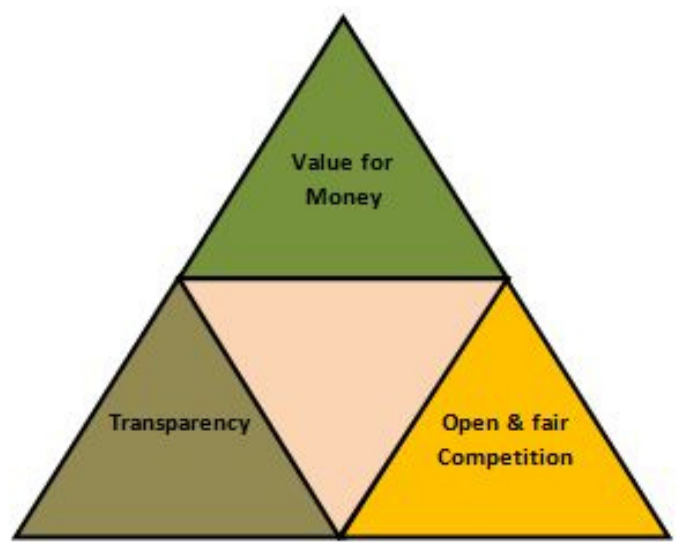

Gambar 1 Prinsip Kebijakan Pengadaan Pemerintah Singapura

Prinsip Transparansi, dalam kebijakan Pengadaan Pemerintah Singapura, dinyatakan dalam pelaksanaan sistem Pengadaan yang transparan dan terbuka. Kebutuhan Pengadaan, prosedur, dan kriteria evaluasi ditampilkan secara terbuka pada portal Government Electronic Business (GeBIZ).

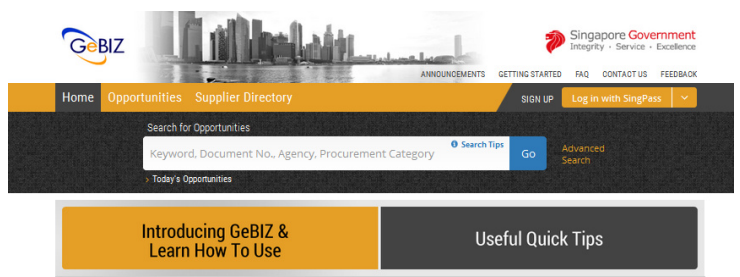

Gambar 2 Portal Pengadaan Pemerintah Singapura

Prinsip Kompetisi Terbuka dan Adil, diterapkan untuk mendorong penyedia layanan/produk pemerintah agar dapat bersaing secara kompetitif dan terbuka dan memberikan penawaran terbaik kepada pemerintah. Semua penyedia diberikan akses dan kesempatan yang sama untuk berkompetisi dalam proses pengadaan. Prinsip ini menjamin tidak ada diskriminasi terhadap penyedia tertentu.

Prinsip Value for Money, diterapkan agar pemerintah Singapura mendapatkan penyedia yang mampu memenuhi kebutuhan pemerintah dengan penawaran harga dan value terbaik. Value for Money ditarik dari analisa biaya manfaat berbasis TCO (Total Cost of Ownership). Oleh karenanya, penyedia dengan tawaran termurah tidak otomatis memenangkan seleksi lelang Pengadaan.
Prinsip Value for Money mempertimbangkan 3 aspek yaitu aspek 3 E's [6]:
Economy
Spend Less
Efficiency
Do things right
Effective
Do the right things

Pemerintah Singapura melalui Badan Auditor pemerintah / Auditor-General's Office (AGO) secara reguler melakukan audit terhadap instansi pemerintah sesuai aturan dan kebijakan Kementrian Keuangan. Audit tersebut dijalankan untuk meningkatkan akuntabilitas pemerintah kepada publik/masyarakat.[7]

\subsection{Kebijakan Pengadaan Teknologi Informasi Pemerintah Australia}

Di Australia, framework kebijakan pemerintah dalam hal pengadaan tercantum dalam Commonwealth Procurement Rules yang digunakan oleh instansi pemerintah untuk mendisain proses Pengadaan. Framework ini berisikan poin-poin prinsip kebijakan yang berlaku untuk segala jenis Pengadaan Pemerintah. Prinsip-prinsip tersebut adalah :

1. Value for money

2. Encouraging competition

3. Efficient, effective and ethical procurement

4. Accountability and transparency in procurement

5. Procurement risk

6. Procurement method

Adapun untuk IT Procurement, Australia menerapkan kebijakan sebagai berikut:

\section{Opt-Out Policy}

Prinsip ini diterapkan untuk sistem pengadaan penunjukan langsung dengan persetujuan Komite khusus yang mereview permohonan instansi pemerintah yang ingin melakukan Pengadaan TI.

Tugas Komite ini adalah mereview permohonan dengan pertimbangan kriteria sebagai berikut :

- $\quad$ Skala ekonomi

- Peluang untuk memberikan layanan yang lebih baik kepada masyarakat dan sektor bisnis

- Penguatan dan pengemabangan kemampuan TI di Australia

- Peningkatan aspek operasional TI pemerintah

- Prioritas pemerintah lain seperti penguatan Usaha Kecil dan Menengah (UKM) dan pembangunan berkelanjutan

- Menghindari duplikasi biaya

- Fleksibilitas sistem TI pemerintahan

- Peningkatan kemampuan dalam merespon tren dan permasalahan TI eksternal

- Kemampuan mengelola dan mendorong aset-aset informasi pemerintah 


\section{SourceIT Model Contracts}

Model kontrak ini menyediakan template bagi organisasi pemerintah untuk mengembangkan perjanjian/agreements dalam pengadaan TI secara lebih efektif dan efisien.

Model kontrak ini didisain untuk menangani jenis-jenis pengadaan sebagai berikut:

- akuisisi hardware dan perawatan

- lisensi dan dukungan software

- lisensi software tanpa dukungan (support)

- jasa konsultansi TI

Model kontrak ini dapat digunakan utk pengadaan sederhana (simple procurement) untuk kebutuhan TI rutin yang sudah ada dengan kriteria:

- resiko rendah

- syarat dan ketentuan digunakan minimal atau tidak ada perubahan

- barang dan jasa tidak membutuhkan pengembangan

- pertimbangan value for money hanya terbatas pada harga, kualitas, kesesuaian tujuan dan jadwal,

- pembayaran umumnya dilakukan pada saat barang/jasa sudah diterima/selesai

- tidak perlu ada saran khusus/ahli untuk pertimbangan legal, kontrak, teknis, atau keuangan.

Model kontrak ini juga dapat digunakan utk pengadaan yang bersifat semi-kompleks. Perbedaannya dengan pengadaan sederhana, kontrak ini perlu saran ahli untuk memastikan ruang lingkup dan risiko setiap pengadaan.

\subsection{IT Procurement Taskforce}

IT Procurement Taskforce adalah satuan tugas khusus untuk pengadaan TI yang dibentuk untuk mewujudkan agenda pemerintah Australia dalam memberikan layanan Digital yang lebih baik dan lebih aksesibel. Satuan tugas ini memiliki dua tujuan, pertama: meningkatkan efisiensi biaya dan mempermudah kerjasama antara dunia usaha TI dengan pemerintah Australia dan kedua: memberikan layanan pemerintah yang lebih baik dengan biaya yang lebih rendah.

Pengadaan TI menjadi fokus karena menjadi pintu masuk/gateway bagi sektor teknologi digital untuk memberikan solusi inovatif kepada pemerintah Australia. Proses ini harus dibuat seterbuka dan sesederhana mungkin agar teknologi baru dapat diimplementasikan secara cepat untuk meningkatkan layanan pemerintahan.

Berdasarkan uraian di atas, maka pertanyaan dari penelitian ini adalah: Apa saja prinsip yang mendasari Kebijakan Pengadaan TI? Apa persamaan dan perbedaan dalam Kebijakan Pengadaan TI di Indonesia, Australia, dan Singapura? Apakah ada acuan standar internasional dalam Pengadaan TI? Apakah Indonesia, Australia, dan Singapura mengimplementasi acuan tersebut dalam Kebijakan Pengadaan TI?

\section{METODOLOGI}

Dalam menentukan kebijakan yang akan dikomparasikan, pencarian dokumen menggunakan mesin pencari internet dilakukan untuk menemukan dokumen kebijakan masing-masing negara. Pencarian dilakukan dalam dua bahasa: Inggris dan Indonesia. Kata kunci yang digunakan adalah "information technology procurement policy" atau "IT policy". Nama negara ditambahkan di depan dua kata kunci untuk mendapatkan dokumen kebijakan masing-masing, misalnya "information technology policy Singapore" atau "kebijakan pengadaan teknologi informasi Indonesia". Selanjutnya, dokumen yang didapatkan kemudian diteliti dan dianalisa untuk mengidentifikasi prinsip-prinsip utama dalam pengadaan Teknologi Informasi setiap negara, Bagian terakhir, membuat tabel berisi kebijakan pengadaan Teknologi Informasi masing-masing Negara. Tabel ini membantu untuk penandaan elemen-elemen yang sama dalam kebijakan pengadaan Teknologi Informasi, selain juga mengenali poin prioritas yang membedakan kebijakan masing-masing negara.

Data dalam penelitian ini adalah data terpercaya, terkini, dan menggambarkan permasalahan secara keseluruhan. Data yang dibutuhkan dalam penelitian ini berupa: Studi kepustakaan (library research), dan survey kuesioner. Sedangkan lingkup penelitian ini adalah Kebijakan Pengadaan Teknologi Informasi di Pemerintahan.

Penelitian ini dilakukan dalam beberapa langkah jalan penelitian, yaitu: Melakukan kegiatan pengumpulan data yang terdiri dari: pengumpulan literatur Kebijakan Pengadaan TI yang berupa buku-buku, hasil penelitian, dokumen obyek penelitian, dokumen peraturan pemerintah terkait, serta sumber lain yang melengkapi pemahaman tentang Kebijakan Pengadaan TI; studi terhadap literatur untuk memahami konsep Pengadaan TI; mengidentifikasi dan menganalisa poin-poin kebijakan yang termasuk dalam domain Pengadaan secara Umum dan Pengadaan TI, termasuk didalamnya melakukan komparasi antar kebijakan dari 3 negara; Menyusun rancangan awal rekomendasi Kebijakan Pengadaan TI; Menguji validasi rancangan rekomendasi Kebijakan Pengadaan TI. Validasi rancangan adopsi Kebijakan Pengadaan TI dilakukan dengan menyebar kuesioner kepada responden; Menyusun ulang rancangan setelah validasi.

Validasi rancangan adopsi Kebijakan ini dilakukan dengan menggunakan metode survey kuesioner. Metode ini secara konsisten digunakan untuk mengukur aspek kualitas. Misalnya, persepsi pengguna terhadap kinerja sebuah layanan. Format rating survey kuesioner umumnya menggunakan 
metode Skala Likert.[8] Dalam skala ini, kualitas ranking responden dari tinggi ke kecil atau baik ke buruk diukur menggunakan 5 atau 7 tingkat skala. Pada penelitian ini aspek kualitas rancangan kebijakan akan diukur melalui hasil kuesioner. Kuesioner dibuat dalam bentuk pertanyaan untuk mengetahui persepsi responden terhadap kebijakan yang ingin diimplementasikan.

\section{HASIL DAN PEMBAHASAN}

Dalam analisis penelitian ini, terkumpul poinpoin kebijakan dari 3 (tiga) negara, yang kemudian diteliti, dianalisa, dan dibandingkan. Kebijakankebijakan itu termuat dalam dokumen yang diambil dari sumber resmi masing-masing negara:

- Indonesia, Peraturan Presiden Republik Indonesia No.54 Tahun 2010 tentang Pengadaan Barang / Jasa Pemerintah

- Singapura, https://app.mof.gov.sg/Policies/GovernmentProcurement

- Australia: Commonwealth Procurement Rules (CPRs), Public Governance, Performance and Accountability Act 2013, Public Service Act 1999

Analisis yang dilakukan terhadap kebijakan Pengadaan baik untuk pengadaan umum maupun Pengadaan Teknologi Informasi mengidentifikasi sejumlah prinsip kebijakan Pengadaan di Indonesia, Singapura dan Australia. Sejumlah prinsip kebijakan yang diidentifikasi ini bukan dimaksudkan sebagai daftar lengkap seluruh kebijakan yang dimiliki oleh 3 negara dalam hal pengadaan/procurement, akan tetapi lebih sebagai daftar indikatif tentang fokus utama prinsip kebijakan pengadaan, yaitu: Efisien, Value for Money, Efektif, Bersaing (competitive), Transparansi, Efektif, Terbuka, Adil, Ekonomis, Etika, Akuntabilitas, Resiko, Metode, Opt-Out Policy, Model Kontrak TI (perangkat keras, perangkat lunak, dan konsultansi). Penjelasan lebih lanjut mengenai identifikasi prinsip dasar Kebijakan Pengadaan Umum dan TI masingmasing negara akan dibahas di bagian selanjutnya.

\section{a. Komparasi Kebijakan Pengadaan Teknologi Informasi (IT Procurement Policy) di 3 Negara}

Agar dapat membandingkan kebijakan pengadaan TI masing-masing negara, maka perlu dibuat daftar prinsip dalam bentuk tabel untuk memudahkan identifikasi kebijakan.

Tabel 1. Identifikasi Kebijakan

\begin{tabular}{||c||l|l|l|}
\hline \hline ISO 20400 & INDONESIA & AUSTRALIA & SINGAPURA \\
\hline Akuntabilitas & Efisien & $\begin{array}{l}\text { Value for } \\
\text { Money }\end{array}$ & Transparansi \\
\hline Transparansi & Efektif & Bersaing & $\begin{array}{l}\text { Terbuka dan } \\
\text { Persaingan } \\
\text { yang Adil }\end{array}$ \\
\hline
\end{tabular}

\begin{tabular}{|l|l|l|l|} 
Etika & Transparansi & $\begin{array}{l}\text { Efektif, Efisien, } \\
\text { Ekonomis, dan } \\
\text { Etika }\end{array}$ & $\begin{array}{l}\text { Value for } \\
\text { Money }\end{array}$ \\
\hline $\begin{array}{l}\text { Stakeholder } \\
\text { Hukum \& } \\
\text { Norma } \\
\text { Internasional }\end{array}$ & Terbuka & $\begin{array}{l}\text { Akuntabilitas } \\
\text { dan } \\
\text { Transparansi }\end{array}$ & Terbuka \\
\hline $\begin{array}{l}\text { Solusi } \\
\text { inovatif dan } \\
\text { transformatif }\end{array}$ & Adil & Risiko & Adil \\
\hline $\begin{array}{l}\text { Fokus pada } \\
\text { kebutuhan }\end{array}$ & Akuntabel & $\begin{array}{l}\text { Kebijakan Opt- } \\
\text { Out }\end{array}$ & Transparansi \\
\hline & Eetode \\
Integrasi & Etika & $\begin{array}{l}\text { Contracts } \\
\text { (hardware, } \\
\text { software, dan } \\
\text { konsultansi) }\end{array}$ & \\
\hline Global cost & & \multicolumn{2}{|l}{} \\
\hline
\end{tabular}

\begin{tabular}{|l|l}
\hline Prinsip Pengadaan Umum \\
Prinsip Pengadaan Teknologi Informasi
\end{tabular}

Dari perbandingan kebijakan ketiga negara, terdapat kesamaan dalam prinsip-prinsip kebijakan Pengadaan Umum. Selain itu, terdapat juga perbedaan prinsip kebijakan, baik dalam Pengadaan Umum, maupun Pengadaan TI.Dalam penetapan urutan kebijakan, dapat diasumsikan bahwa urutan kebijakan menggambarkan prioritas prinsip Pengadaan di masing-masing negara. Bagian selanjutnya akan membahas tentang persamaan prinsip kebijakan di 3 (tiga) negara.

\section{b. Analisis Kebijakan Pengadaan TI di Indonesia}

Indonesia sebagai negara Republik mengadopsi 7 (tujuh) prinsip dalam kebijakan Pengadaan, hasil dari penerapan kebijakan itu ditetapkan dalam regulasi berupa Perpres tentang Pengadaan. Implementasi dari Perpres mengatur beberapa hal, yaitu: 1)Sistem Pengadaan di Indonesia harus berbasis TI, yaitu e-Procurement sebagai wujud dari prinsip kebijakan efisien, efektif, akuntabel, bersaing, adil, terbuka, dan transparan.(2), Perpres mengatur tentang standar Dokumen Pengadaan, (3) Perpres mengatur organisasi terkait Pengadaan, (4) Dokumentasi pengadaan yang lebih baik, sebagai implementasi prinsip kebijakan akuntabel.

\section{c. Analisis Kebijakan Pengadaan TI di Australia}

Pemerintah Australia menerapkan 8 (delapan) prinsip kebijakan pengadaan. Implementasi dari prinsip kebijakan tersebut antara lain adalah: (1) Adanya aturan Commonwealth Procurement Rules ditetapkan pemerintah Australia sebagai implementasi dari prinsip pengadaan secara umum. (2) Khusus untuk Pengadaan TI, pemerintah Australia membuat aturan turunan dari Commonwealth Procurement Rules. (3) Australia 
menerapkan pengadaan secara elektronik yang konsepnya secara terpusat atau terpadu. (4) Khusus untuk pengadaan TI, Australia membentuk satuan tugas pengadaan TI atau ICT Procurement Taskforce. (5) Untuk pengadaan TI, Australia menerapkan prinsip kebijakan Opt-Out, yang memungkinkan untuk dilakukan penunjukan langsung pada vendor penyedia layanan barang/jasa TI. Kebijakan ini dilakukan dengan memperhatikan beberapa aspek tertentu yang harus dipenuhi.

\section{d. Analisis Kebijakan Pengadaan TI di Singapura}

Singapura adalah negara yang menerapkan prinsip yang paling sederhana dalam kebijakan Pengadaan TI. Prinsip pengadaan di Singapura hanya mengacu pada tiga prinsip yaitu; value for money, transparency dan open and fair competition. Berikut adalah dampak dari implementasi kebijakan pengadaan di Singapura berdasarkan analisa studi pustaka yang dilakukan oleh peneliti. (1) Singapura telah menerapkan proses pengadaan Teknologi Informasi berbasis elektronik (e-procurement) dengan konsep satu portal. (2) Dengan konsep satu portal, Singapura memiliki organisasi khusus yang menangani proses pengadaan seluruh kebutuhan pemerintah tanpa mengkhususkan pada pengadaan TI. (3) Untuk pengadaan yang bersifat rutin di Singapura diterapkan kebijakan bulk tender.

\section{e. Persamaan Implementasi Kebijakan Pengadaan Umum Indonesia dengan Australia dan Singapura}

Mengacu pada analisa di masing-masing Negara diatas, maka peneliti menemukan beberapa persamaan dalam hal pengadaan TI. Persamaan tersebut adalah sebagai berikut. (1) Ketiga Negara memiliki kebijakan yang telah diturunkan dalam aturan-aturan atau regulasi pengadaan. (2) Ketiga Negara telah mengimplementasikan system pengadaan dengan berbasis elektronik/eprocurement (3.) Pelaksanaan proses pengadaan dilakukan oleh organisasi khusus yang bertanggung jawab terhadap kegiatan pengadaan. (4) Dokumen pengadaan telah terstandarisasi. (5) Untuk pengadaan tertentu ketiga Negara dapat melakukan dengan penunjukan langsung tanpa melakukan proses lelang.

Beberapa kesamaan poin prinsip kebijakan Pengadaan Umum di antara Indonesia, Australia, dan Singapura adalah pada poin-poin Efisiensi, Transparansi, Efektifitas, Persaingan, Terbuka, Adil, dan Akuntabilitas.

\section{f. Perbedaan Implementasi Kebijakan Pengadaan Umum Indonesia dengan Australia dan Singapura}

Perbedaan yang peneliti temukan dalam pengadaan khususnya pengadaan Teknologi Informasi di ketiga negara ini adalah sebagai berikut: (1) Dalam pelaksanaan e-procurement, pemerintah Indonesia berbeda dengan Australia dan Singapura. Indonesia menerapkan proses pengadaan TI yang dilakukan secara mandiri oleh masing-masing instansi dimana hak pengelolaan dan pengaturan pengadaan diserahkan kepada masing-masing instansi, adapun pemerintah pusat hanya bertindak sebagai pembuat kebijakan, aturan dan pengawas pelaksanaannya saja. Sedangkan di Australia dan Singapura, pelaksanaan proses pengadaan dilakukan secara terpusat, dimana semua proses pengadaan dilakukan oleh pemerintah pusat dengan satu portal. (2) Indonesia dan Singapura belum memiliki organisasi khusus yang mengatur pelaksaan pengadaan TI sedangkan Australia sudah memiliki organisasi yang mengatur secara detail proses pengadaan TI, yaitu ICT Procurement Taskforce.

Beberapa perbedaan poin prinsip kebijakan Pengadaan umum di antara Indonesia, Australia, dan Singapura, antara lain adalah: (1) Prinsip Value for Money, (2.) Prinsip Risiko Pengadaan (3).Prinsip Metode Pengadaan.

\section{g. Rekomendasi Kebijakan Pengadaan TI}

Setelah melakukan komparasi, ditemuka beberapa perbedaan dalam aspek kebijakan pengadaan TI yang belum ada di Indonesia. Untuk mencoba menyempurnakan kebijakan pengadaan yang telah ada, peneliti kemudian membuat survei kuesioner berisikan pertanyaan tentang kebijakan pengadaan TI, yang hasilnya kemudian dapat menjadi landasan penyempurnaan kebijakan pengadaan yang telah ada. Kuesioner ini diberikan kepada pegawai pemerintah yang terlibat langsung dalam proses Pengadaan TI. Pada penelitian ini, pegawai pemerintah yang menjadi responden adalah pegawai yang bertindak sebagai Kuasa Pengguna Anggaran (KPA) bidang TI, pegawai yang bertindak sebagai anggota Unit Layanan Pengadaan (ULP), dan Pejabat Pembuat Komitmen (PPK).

Data yang akan dianalisis merupakan hasil jawaban dari 5 (lima) responden dari kuesioner yang telah mereka terima. Penilaian kuesioner yang diberikan pada variabel, bergerak dari angka 1 hingga 5. Semakin tinggi penilaian yang diberikan, maka dipersepsikan bahwa tingkat kebutuhan penerapan akan semakin kuat.

Untuk mengetahui tingkat skor atau tinggi rendahnya skor penilaian dari masing-masing variabel maka perlu ditentukan nilai intervalnya. Berdasarkan skala Likert, ditentukan kriteria interval sebagai berikut :

Tabel 2. Skala Likert Kriteria

\begin{tabular}{|l|l|}
\hline $0-19,99 \%$ & Sangat Tidak Perlu \\
\hline $20 \%-39,99 \%$ & Tidak Perlu \\
\hline $40 \%-59,99 \%$ & Kurang perlu \\
\hline $60 \%-79,99 \%$ & Perlu \\
\hline $80 \%-100 \%$ & Sangat Perlu \\
\hline
\end{tabular}


Berdasarkan pada kuesioner yang disebarkan pada 5 (lima) responden maka diperoleh hasil sebagai berikut:

Tabel 3. Hasil Kuesionner Responden

\begin{tabular}{|l|l|l|}
\hline Pertanyaan & $\begin{array}{l}\text { Tingkat } \\
\text { Persetujuan } \\
\text { Responden }\end{array}$ & Hasil \\
\hline $\begin{array}{l}\text { Perlukah dibuat regulasi } \\
\text { khusus yang mengatur } \\
\text { pengadaan TI? }\end{array}$ & $84 \%$ & $\begin{array}{l}\text { Sangat } \\
\text { Perlu }\end{array}$ \\
\hline $\begin{array}{l}\text { Perlukah dibentuk } \\
\text { organisasi khusus } \\
\text { (special taskforce) } \\
\text { untuk pengadaan TI? }\end{array}$ & $72 \%$ & Perlu \\
\hline $\begin{array}{l}\text { Perlukah dilakukan } \\
\text { proses sentralisasi } \\
\text { dalam pengadaan TI? }\end{array}$ & $40 \%$ & $\begin{array}{l}\text { Kurang } \\
\text { Perlu }\end{array}$ \\
\hline
\end{tabular}

Secara umum kebijakan pengadaan yang diterapkan oleh Indonesia, Australia, dan Singapura telah diatur dalam regulasi yang menjadi panduan dalam penerapan pengadaan, namun khusus pengadaan TI hanya pemerintah Australia yang memiliki kebijakan khusus terkait hal tersebut. Berdasarkan hasil dari kuesioner, responden setuju adanya regulasi khusus dalam hal pengadaan TI dan pembentukan adanya unit khusus berkaitan pengadaan TI. Sedangkan, untuk sentralisasi, responden menganggap tidak perlu dilakukan.

\section{KESIMPULAN}

Identifikasi, analisis, dan komparasi kebijakan tiga negara dalam hal Pengadaan Teknologi Informasi (IT Procurement Policy). Pertama, secara umum, ketiga negara memiliki kesamaan dalam prinsip-prinsip kebijakan Pengadaan Teknologi Informasi masing-masing. Kesamaan terdapat dalam beberapa prinsip seperti prinsip Efektivitas, Efisiensi, Transparansi, Persaingan, Terbuka, Adil, dan prinsip Akuntabilitas. Kesamaan ini pada dasarnya adalah kesamaan prinsip Pengadaan secara umum yang melingkupi proses Pengadaan seluruh barang/produk dan jasa/layanan yang dibutuhkan pemerintah, termasuk kebutuhan pengadaan Teknologi Informasi.

Perbedaan terletak pada implementasi kebijakan, misalnya di Australia, prinsip efektivitas dan efisiensi dikembangkan secara khusus untuk Pengadaan TI dengan dibentuknya beberapa regulasi khusus. Regulasi khusus/spesifik untuk IT Procurement di Australia adalah opt-out policy dan template kontrak khusus untuk pekerjaan di bidang TI. Selain itu, khusus untuk menangani pengadaan bidang TI, Australia telah membentuk IT Procurement Taskforce.

Pemerintah Indonesia perlu melakukan penyempurnaan implementasi kebijakan Pengadaan dengan memberikan perhatian khusus pada Pengadaan TI melalui adopsi IT Procurement
Policy dari negara-negara yang telah maju seperti Australia dan Singapura.

\section{DAFTAR PUSTAKA}

[1]. R. M. Harahap, "Analisis Permasalahan Pengadaan Infrastruktur TI Instansi Pemerintah: Pengalaman dari Pendampingan BPKP," CommIT, vol. 1, no. 2, pp. 167-172, 2008.

[2]. A. C. R. and M. K. S. Moe, Carl Erik, "Limits of Public Procurement: Information Systems Acquisition," Egov 2006, no. 2, pp. 281-292, 2006.

[3]. C. E. Moe and M. Newman, "The public procurement of IS - A process view," Proc. Annu. Hawaii Int. Conf. Syst. Sci., pp. 21582167, 2014.

[4]. H. Walker, J. Mayo, S. Brammer, A. Touboulic, and J. Lynch, "Sustainable Procurement: an International Policy Analysis of 30 Oecd Countries," 5th Int. PUBLIC Procure. Conf., pp. 3556-3582, 2012.

[5]. Presiden RI, "Peraturan Presiden No. 54 Tahun 2010 tentang Pengadaan Barang / Jasa Pemerintah," 2010.

[6]. Singapore. Civil Service College, "Value for Money in Singapore's Government Procurement Regime," Sixth Reg. Public Procure. Forum, pp. 1-10, 2010.

[7]. "Government Procurement." [Online]. Available:

http://www.mof.gov.sg/Policies/GovernmentProcurement. [Accessed: 16-Jan-2017].

[8]. I. Elaine, "Likert Scales and Data Analyses," Qual. Prog., vol. 40, no. 7, 2007. 